\title{
INDONESIAN CONTEXT OF THE MEANING OF QUR'AN: A STUDY ON THE VERSES OF POWERS IN TAFSIR $A L$ - AZHAR AND AL-MISHBAH
}

\author{
Anwar Mujahidin \\ State Institute of Islamic Studies (IAIN) Ponorogo \\ anwarmujahidin@iainponorogo.ac.id
}

\begin{abstract}
The presence of interpretation (tafsir) books as the work of Indonesian from many generations indicates the existence of reading and understanding activities towards the Qur'an in the Indonesian context. This interpretation shows a correlation between the text world, namely the Qur'an, and the reader's concrete world which is Indonesian society. This research is going to analyze how the method and approach used by Tafsir al-Azhar and al-Mishbah to contextualize the meaning of the verses in the Qur'an related with the theme of authority or power of state and government. This research is going to use thematic and analytical approach by analyzing the interpretation of the verses which are related to the authority concept, state and government. The result of this research indicates that both al-Azhar and al-Mishbah contextualize the meaning of verses in the Qur'an by bringing them into general value. The differences among them, Quraish Shihab, lays out the general understanding of general knowledge. Meanwhile, Hamka lays out the general meaning into a more concrete thinking which is more actual in the Indonesian context.
\end{abstract}

Keywords: Contextual Interpretation, Interpretation of Qur'an in Indonesia, Power, State, Government.

\section{Introduction}

The birth of a work of interpretation in various regions from generation to generation is not only because of the intention to reveal the meaning of the Qur'an, or the transfer of the Arabic language to non-Arabic language. If the intention is only motivation, the interpretation or explanation of the first generation of scholars has sufficed these needs. The relation both interpreter's and text is not an objective of relationship. It means when the interpreter obeys a particular method, it will surely achieve the intended truth. According to Paul Ricoeur's hermeneutics, the text has a conception that: 1) Writing will fix the meaning (fixation of the meaning); 2) By writing, the intent of the author will be separated from the meaning of the text itself. The text will wander with its own world, regardless of the author's horizon; 3) by writing, the text will go beyond the initial reference when it is delivered (Bleicher, 1993, p.23, Recour, 1991).

Recour's hermeneutic view and some other hermeneutic theories which are represented in the study of Qur'an open the new path for the study of the Qur'an interpretation work. The work of interpretation is not only a work aimed at expressing the intention of the author having been imprinted into the text of the Qur'an. Tafsir of the Quran became an attempt to reveal the meaning of the Qur'an which has been understood by the first recipient, namely the Arab society of the revelation period. Tafsir also simultaneously shows the mission of the interpreter to bring the meaning of the Qur'an to the community that surrounds the interpreter. The interpreter's relationship as a reader with the Qur'an in the context of cultural relations rather than the purely theological relation has been parsed by Nashr Hāmid Abū Zayd in his great masterpiece, Mafhūm al- 
Nash (Zayd, 2000, p.25). Thus, the Indonesian mufassir's attempt to create a work of Qur'an interpretation is understood as an attempt to present the meaning of the Qur'an in the Indonesian meaning context. In the work of Indonesian interpretation, it is implied the process of understanding for Indonesian socio-cultural readers and interpreters.

The presence of the work of Tafsir in Indonesia from the works of Indonesians from many generations indicates the existence of reading and understanding activities of the Qur'an in the Indonesian context. The work of interpretation signifies a connection between the textual world, namely the Qur'an and the reader concrete world, namely Indonesian people. The work of the Qur'an interpretation cannot be separated from the interpreters and many things around them including the cultural background. According to the article quoted by Imam Muslih, the interpretation of the Qur'an is an intellectual construction of an exegete (Mufassir) to explain the God's revelation written in the Qur'an which is based human needs in the social and cultural environment with the complexity of values that surround it (Muhsin, 2010, p.6).

In the Indonesian context, various books of tafseer have existed since Indonesia's independence or Indonesian development within the framework of the Republic of Indonesia. According to Federspiel, from the beginning of the twentieth century to the early 1960s, the interpretive activity is characterized by the translation of the Qur'an and the fragmentary interpretation. The period is classified as the first generation followed by the second generation that emerged in the mid-1960s as a refinement of the efforts of the first generation (Federspiel, 1996, p.123).

Federspeil did not conduct the research about Qur'an study until reformation period when al-Mishbāh was created. Nevertheless, Federspiel has read the works of Quraish Shihab. They are "Groaning the Qur'an and Insights of the Qur'an.” According to his commentary, Quraish Shihab has determined the standard for every new set of works on Islam, related to contemporary Indonesian Muslim interests (Federspiel 1996, pp. 299$300)$.

The number of works on the Qur'an interpretation in Indonesia invites a big question whether the works of Indonesian tafseer which is continually born from generation to generation is merely a mainstream interpretation of Qur'an existed in Arabic, or whether it presents something new and different, so that the work of interpretation is meaningful and contextual for Indonesia people. The question prompts a very interesting and important study to analyze the Indonesian context of Indonesian tafsir works. This study will observe how the methods and approach of the Indonesian interpreters in contextualizing the meaning of the Qur'an and the extent of their actual interpretation for the Indonesian people who surround them.

The research focusing on the study of the Indonesian tafsir is quite a lot. One of them is the author's dissertation entitled The Concept of Power in Tafsir al-Mishbāh of M. Quraish Shihab and Its Relevance to The Transformation of the Indonesian Society. (Mujahidin, 2011). The research focuses on the digging of power concepts regarding sociological theory and its relevance to the transformation of Indonesian society in the global era. Secondly, the Thesis of Ali Muhatarom entitled The Concept of Satrul 'Aurah according To Hamka's Interpretation In al-Azhar and M. Quraish Shihab Interpretation in al-Mishbāh (Comparative Study). This thesis focuses on comparative studies to find the ethical dress of the two interpreters with the aim that the society can dress up according to the Qur'an but not left behind in terms of fashion development (Muhatarom, 2015). The next is Abdul Wahid's paper entitled, Social Politics in Hamka's Tafsir. This paper deals only with al-Nisā 'verses 59 and 58 to discover how the results of Hamka's interpretation is and whether Hamka is affected by the current political and social situation at both international levels on the Islamic world and local level of Indonesia 
(Wahid, 2016). The author also found a paper on Hamka from Syed Muhd Khairudin Aljunied In entitled, "Defense of Guided Reason: Hamka and the Reconstruction of Southeast Asian Islam" (Aljunied, 2017). From some results of the study, no one has seen the work of Indonesian tafsir in the context of a dynamic context-textual relationship such as hermeneutic theory.

This research will be focused on analyzing the work of al-Azhar tafsir by Hamka and al-Mishbāh tafsir by M. Quraish Shihab. Both works represent different generations, where al-Azhar represents the second generation and al-Mishbāh represents the contemporary generation. Al-Azhar was written in the early 1950s when Indonesia was establishing the basics of the country. Tafsìr al-Mishbāh was then emerged during reformation era in the 2000s. It is more moderate, comprehensive and has many references and takes up more about the context of modern social life reality. The study will focus on the verses which are related directly or indirectly to the power, government, and state, so it is hoped that this research will be able to find the methods of the two interpreters on how to contextualize the verses about power, state and government in the space of political thought Islam of the Indonesia.

The research will use the thematic tafsir approach (Muslim, 1989, pp. 16-17). It begins by finding the verses talking about the government and power. Afterwards, it will be looked for the interpretation of the verses by Hamka in tafsir al-Azhar and Quraish Shihab in tafsir al-Mishbāh. The data collected is then analytically analyzed to find parts of the interpretation which indicate the socio-cultural background to Indonesia. In the next steps, the contextual elements of the two books of tafsir are analyzed, their relationship to the discourse of authority, the state and government developing in Indonesia when the two books of interpretation emerged, so that the relevance of the context of interpretation is known.

\section{Context of Tafsir of Authority and Governance}

Context is the situation or background which communication occurs. Context can be regarded as the cause and reason for a conversation or dialogue. (Mulyana, 2005, p. 21) The context of discourse is shaped by various elements, such as situations, speakers, listeners, place and time, scenes, topics, events, forms of commands, codes, and channels (Djajasudarma, 2006, p.27). Nevertheless, context is not such a purpose or direct cause, but a subjective construct of interaction results by dialogue participants as members of groups and community members. If the context is objective, it will be an obstacle for everyone because people have to speak the same way in the same social situation (thus, context is not objective condition. Participate as members of groups and communities (Dijk, 2008, p. ix) If contexts were objective social conditions or constrain, all people in the same social situation would speak in the same way(Dijk, 2008, p. ix).

Abdullah Saeed, an expert of Qur'an study emphasizing the contextual meaning of Qur'an states that Muslim Scholar tends to view the Qur'an as a source of practical guidance to be implicated in and different situation and situation, not merely a set of rigid law. Muslim Scholar who uses this contextual approach argues that an interpreter must know the context of the social, political, and culture time of revelation of the Quran revealed and also the context of what happened today. Thus, sub-discussion of tafsir context will seek the parts of interpretation of al-Azhar and al-Mishbāh indicating Indonesian cultural background (Najib, 2016, p.92).

Saeed's thought about Qur'an contextual is affected by Fazlur Rohma's view. For Saeed, Rahman, who is one of Muslim leaders were very instrumental in developing a contemporary approach on the Qur'an. The theory developed by Saeed taken from Rahman is a double movement theory. For him, this theory has provided new color in 
thinking. Saeed later developed his own. Double movement is a process of interpretation that sees reality occurring now, then sees the revelation of the Qur'an to take their message, and then to apply it in the nowadays life (from the present situation to Qur'anic times, then back to the present) (Najib, 2016, p.92).

The terms in the Qur'an referring to the meaning of authority and governance are varied, such as mulk, sulthān, ülì al-amrand so on (Mujahidin, 2011). Al-Mishbāh views that the base of discussion in relation with authority and government can be found at $A n$ Nis̄a 59 and Äli-'Imrān 26. Quraish clarifies that in the part of Sura al-Nisa 59, there is a term, $\bar{u} \bar{l}$ al-amr, which is in appropriate with the present community. According to Quraish Shihab, $\bar{u} l \bar{l}$ al-amr is the people authorized to take care of Muslim society. They consist of government ulama, authority, and they represent society in many groups and their professions. In the deeper analysis about the plural form of the word $\bar{u} l \bar{l}$, he has a more tendency on the opinion stating that the expalanation of $\bar{u} l \bar{l}$ al-amr means an institution or person having legal authority to instruct in their own fields (Shihab, 2005, pp. Vol. 2, 484).

After the term of $\bar{u} l \bar{l}$ al-amr which refer to authority functionary either government or social can be contextualized, Quraish Shihab then makes a general principle based on the interpretation of $a t h \bar{\imath} ' \bar{u}$, related to the obidience between society and $\bar{u} l \bar{l}$ al-amr. The society must submit to $\bar{u} l \bar{l}$ al-amr whether they like or not as long as $\bar{u} l \bar{l}$ al-amr obey to Allah.

There is no obedience in rebellion or commiseration to God. According to Quraish Shihab, obedience in the context of Qur'an means submission, receive sincerely, or accompany. Thus, such obedience is not merely to carry out what is commanded, but also to participate in the efforts made by the government to support society services. Society participation is a kind of positive support, including social control for the success of the tasks they hold (Shihab, 2005, pp. Vol.2 484-486).

After the term $\bar{u} l \bar{l}$ al-amr can be contextualized today, which refers to both governmental and social authorities, then Quraish Shihab then makes a general principle, based onthe interpretation of the word $a t h \bar{\imath} \bar{u}$, of the relation between the community and $\bar{u} l \bar{l} a l$-amr. The people must obey $\bar{u} l \bar{l}$ al-amr like or dislike as long as $\bar{u} l \bar{l}$ al-amr is obedient to Allah. There is no obedience in rebellion or commiseration to God. According to Quraish Shihab, obedience in the Qur'an language means submission, receives sincerely. Thus, such obedience is not merely to carry out what is commanded, but also to participate in efforts made by the ruler to support efforts of community service. Community participation is positive support; including social control for the success of the tasks they hold (Shihab, 2005, pp. Vol.2 484-486).

The method of contextualization done by Quraish Shihab by formulating towards general principlesalso appears in the interpretation of surah Ali 'Imrān 26. In this verse, it is stated that the power of commanding (political power) led by human being on earth is the gift of God by His will, and then God can take it back whenever He wishes. The mechanism of granting and abrogation is discouraged as something through the mechanism of the law which God has instituted and applied in the life of society as in the God decision (Shihab, 2005, pp. 2, 56).

The single source of power originating only from God and the withdrawal of the whole structure of the discourse of a verse to God is a reflection of the religious view of Sunni-Salafist interpreter (M. Quraish Shihab) with Bayani-textualist framework. One characteristic of Bayani's reasoning is the view which does not ask much about why and how (lâ kayfa), (Abdullah, 2001). The view is reflected in the interpretation of Áli 'Imrān: 26. Quraish Shihab in the interpretation of it states that the kingdom, the power which is in the human hands, is not his. Therefore, if he is not sincerely to hand it over when God 
ask it him back, God will deprive the kingdom which He has ever given. How does God's mechanism of giving and abrogating the power that has been held by humans? According to Quraish Shihab, Allah has a way that cannot be restricted by human reason, just like the laws of nature which He set in the journey of this universe (Shihab, 2005, pp. Vol.2, 54-56).

Hamka interprets the meaning of $\bar{u} l \bar{l}$ al-amr as the people who are really good at their work, the people who are in power among you. Hamka then highlights the word minkum ( $\bar{u} l \bar{l}$ al-amrminkum). According to Hamka, the word minkum contains two meanings, first people among you, and second, people from you. Those who have a power come from your group as well, they are ascendent or elected or you recognize his power as a reality (Hamka, 2015, pp. 2, 341).

Hamka then made the expected contextual norms for Indonesian at that time. In the term of power responsibility, state affairs are divided into two parts, which are about religion solely and which concern about the general affairs. Religious matters merely await the commands of the Apostles and Messengers based on God's revelation. But general affairs such as war and peace, building places of worshiping, and farming, raising livestock and others, are given to you yourselves. The main basis is syüra which means deliberation. The result of deliberation becomes a decision that must be obeyed by all Muslims. The people keeping the running of syura are then called ùlī al-amr. Society has given its affairs to the expert, and then obeys to what they decided (Hamka, 2015, pp. 2, 341). Such obedience to $\bar{u} \bar{l}$ al-amr's decision becomes the third obligation in religion, which is as powerful as the obedience to Allah and the Messenger (Hamka, 2015, pp. 2, 342).

The discourse of the separation between mere religious affairs and public affairs is the choice that Hamka makes, in accordance with the experience and knowledge of Indonesian-owned by the interpreters. It is known that Indonesia is not an Islamic country which bases its state on Islamic shari'a. Thus, issues of power, politics, and government which are regarded as general affairs, are a moderate perspective for Muslims. Hamka promotes one condition which although government is a general affair, they must avoid unhealthy decisions for religious people. Therefore, all decisions taken by $\bar{u} l \bar{\imath}$ al-amr should be based on the consensus decision.

As known in the Indonesia's pre-independence history, Muslim were actively involved in laying the foundations of the state. Was Islam used as the basis of the state or just a source of moral values? The debate surfaced in the BPUPKI council. (Soraya, 2014, pp. 2-3). Supomo described the idea of an Islamic state and the idea of a state based on the lofty ideals of Islam. According to him, in a country organized as an Islamic state, the state cannot be separated from religion. The state and religion are one, united, and the shari'a law is regarded as God's command to be the basis used by the state. Supomo, however, recommended that the state of Indonesia not be an Islamic state, but to be "a state based on a moral principle advocated by the Islamic religion (Soraya, 2014, p.4).

Hamka interprets al-Mulk in Āli 'Imrān: 26 as the nubuwah power of prophethood, not a power in general as Quraish Shihab's opinion.According to Hamka, the context of $\bar{A} l i$ 'Imrān26 is the rise of nubuwat'slight brought by the Muhammad. Muhammad was sent by Allah to be an Apostle. The main task is to teach human beings to believe in God, but the result is a power, a government with prestige and splendor, making war covenants, or peacefully, punishing the guilty, until it is also entitled to punish with a kill. Muhammad prophethood (PBUH) made Israel unlikely to acknowledge the reality (Hamka, 2015, pp. 1, 605-606).

In the present context, Hamka states that Muhammad came with an ideology, namely Islam. It was then formed a power itself in Medina, not he first pursued a power 
and then the ideology was arranged (Hamka, 2015, pp. 1, 606). The development of ideology as a type of Islamic movement in Indonesia is a stage of Muslim history in Indonesia in Hamka's period. Kuntowijoyo stated that Indonesian Islamic society has passed through three periods, which are called myth, ideology and science period. The ideology period was marked by the founding of the Sarekat Islam (SI). In this period, the people had thought rationally but it was still illogical in the form of a priori knowledge about abstract values. Muslims were really considered to start thinking logically in the period of science marked with the Islamic ideology with the release of the mass organization law (UU Ormas) in 1985. (Kuntowijoyo, 2004, pp. 80-81).

\section{Context of Interpretation of the Verses about Obtaining Power and Leadership}

The Quraish Shihab method by formulating general principles in contextualizing the interpretation of a verse in the Qur'an, appear in one episode of Abraham story placed in al-Baqarah 124-0126. The part to which Quraish Shihab pays attention is the statement "Inn̄ jā'iluka li al-nāsi imām", meaning that I will make a priest for all mankind. Quraish Shihab further explains the important values that the verse implies with its examples. The first value, that leadership and exemplary are derived from God, and not based on lineage, kinship or familiy relation. The second value is that leadership and exemplary should be based on faith and piety, knowledge, and success in various tests. Leadership will not be conferred by Allah to those who do wrong(Shihab, 2005, pp. Vol.1, 318)

Regarding the criteria of the leader and the way to gain a power concretely can be seen in the story of the appointment of Thālut as the king of Israel in the interpretation of al-Baqarah 247. It tells about the rejection of the leaders of Israel to the appointment of Thàlūt as a king. Quraish Shihab on the one hand is at the point of view receiveing suprarational understanding that the appointment of the king of Israel is at God's will in absolute terms. Based on the verse "God gives His power to whom He will, based on His wisdom. And, God is the most All-Wide power, majesty, and sustenance, Knowing ", Quraish Shihab concludes that the passage is an affirmation that God as the source of power has the absolute right to appoint and dismiss a king, so if people do not know the reason for the king's appointment, they cannot object it because Allah is the owner of power (Shihab, 2005, pp. Vol 1, 532).

The dichotomy between rational powers based on the rules of law with God's absoluteness and willingness is compromised by Quraish Shihab through the conclusion in tafsir of al-Baqarah 247. Quraish Shihab makes a conclusion that shows a rational attitude about how God's absolute right as the source of power operates within a real political world in a way. According to Quraish Shihab, that:

The authority to rule is not on the basis of offspring, but on the basis of physical knowledge and health, even here it is implied that His sovereign power is derived from Him, in the sense of a good relationship between the commander and Allah. On the other hand, this verse implies that if you want to vote, do not be deceived by heredity, social standing, or popularity, but should be on the basis of possession of qualities and qualifications that can support the task to assign for those chosen (Shihab, 2005, pp. Vol.1, 532).

Thus, in general there are two paths to gain political power between rational efforts by improving competence in the field of tasks to be carried out such as the mastery of science, the improvement of mental attitude with the properties of praise, such as trust, honesty, and responsibility and increase physical strength. In addition to the rational path, there are some efforts to establish power to come up supa-rational things, by improving 
good relations with God. As confirmed in the next verse from the story of Thâlut's appointment as a king for Israel contained in al-Baqarah 248.

The relevance of al-Mishbāh to the verses on how to gain power can be attributed to the book Quraish Shihab, the Qur'an Insight which examines the political themes in the Qur'an. He, Quraish Shihab, states that establishing a praying is a good relationship with God and giving tax (zakat) is a symbol of attention directed to a weak society (Shihab, Wawasan al-Qur'an: Tafsir Maudhu'i atas Pelbagai Persoalan Umat, 1996). Thus Quraish Shihab, is more likely on the perspective of 'worship' in politics. The piety of the leader and the politician is measured from his piety and personal relationship with God. The worldview of Islamic worship makes one less critical of political power, because Islam will only become a moral religion that conveys individual values (Haryatmoko, 2003, p.23).

The above political views have led the writer of $a l-M i s h b \bar{a} h$ to be able to foster good relations with the former president of Indonesia, Suharto. During the regim of the New Orde, Suharto showed himself as a Muslim who diligently prayed, ever went for Hajj, used to devine tax , and used ot give qurban on Iedl Adha. As stated by Nurkholish Madjid, Soeharto as the central figure of the New Orde has combined the hierarchical view of the military with the pattern of the superior command line of obedience to the strict subordinates on the one hand, and the concept of Javanese social and cultural stratification with paternalistic observance on the other hand (Baso, 1999, p 20). AlMishbāh'sauthor gained the confidence of being a minister of religion at the end of Suharto's term. Quraish Shihab was also active in the MUI and became chairman of the central MUI in 1984-1998, Director of the MUI in 1994-1997 (Shihab, 2005).

Al-Azhar also highlights the issue of the conferment of a power to a person as in the interpretation of al-Baqarah 124. According to Hamka, after passing all the tests and fulfill them as best as possible, Allah then said to Ibrahim in the continuation of verse 124, that Allah wants to make Ibrahim as Imam for all humanity. According to Hamka, the passages provide a very profound lesson about the glorious position that God bestowed upon one of His Apostles. After he graduated in such a variety of heavy tests and overcome them triumphantly, God gave him the title of priesthood for man. The Imam is the person to follow, the person who is the pioneer, who should be imitated, whether in regard to religion and worship, or morals (Hamka, 2015, pp. 1,).

After the power was given by God to Abraham, he appealed to God that the power was also given to those chosen by God from among his offspring. Hopefully the people would connect his efforts. God responded to Abraham's request, that God would grant his prayers so that from his descendants there would be priests, as a continuation of his efforts. But God's promise did not give it to his despotic offspring. The virtue, the height of religion and worship are not due to heredity. (Hamka, 2015, pp. 1,).

Hamka interprets al-Baqarah 247 and 248 under the title "Choosing the Leader". Through the verse, according to Hamka, the Qur'an left two basic points for choosing the person who will be the leader or peak of power. Firstly, the science, the two bodies, especially the science of the task that is facing him, so he did not hesitate to run the leadership. The most important thing is the science in manging human resources. The supreme leader does not need to know all the branches of knowledge, but they are obliged to know the choice of personnel to be assigned to a job. That's the science of the leader. Put the person in his place, the right man in the right place. (Hamka, 2015, pp. 1, 484).

Furthermore, on the interpretation of verse 248 about the heirloom named tabut, Hamka interpreted tabutwith a rational thought flow. Tabut is the sacred treasure chest of the prophet Moses as a place of laying the relics of the treaty of Israel with God. Because it contained a script that was remembered by Israel, the existence of the coffer reassured 
the heart and made the fighting spirit arise. Hamka considers many irrevocable israiliyah stories related to the sakinah and tabut interpretations. According to Hamka, it refers to powerful sources such as Ibn Abbas which states that sakinah means thuma ninah. Or the interpretation of al-Hasan, sakinah is what makes their hearts serene. It is related to tabut, that apart from the trunk (tabut) there is something reassuring from the Lord, there is also a remnant of what the family of Moses and the Aaron (Harun) family left behind. Rest is a translation of baqiyatun. Hamka then concludes that "We know both in our antiquity and modern times today, deliberately created a symbol to make up the determination and thrill. Created a symbol and then defended furiously "(Hamka, 2015, pp. 1, 486).

Furthermore, on the interpretation of verse 248 about the heirloom named tabut, Hamka interpreted tabut with a rational thought flow. Tabut is the sacred treasure chest of the prophet Moses as a place of laying the relics of the treaty of Israel with God. Because it contained a script that was remembered by Israel, the existence of the coffer reassured the heart and made the fighting spirit arise. Hamka considers many irrevocable Israiliyah stories related to the sakinah and tabut interpretations. According to Hamka, it refers to powerful sources such as Ibn Abbas which states that sakinah means thuma ninah. Or the interpretation of al-Hasan, sakinah is what makes their hearts serene. It is related to tabut, that apart from the trunk (tabut) there is something reassuring from the Lord, there is also a remnant of what the family of Moses and the Aaron (Harun) family left behind. Rest is a translation of baqiyatun. Hamka then concludes that "We know that both in our ancient and modern times like today, it is deliberately created a symbol to make up the determination and thrill the spirit. It is also made a symbol and then defended furiously "(Hamka, 2015, pp. 1, 486).

Hamka's more idealistic, critical, and rational reason makes Hamka has a dynamic relationship with government. He was willing to accept the position of the first MUI chairman with his famous revelation of MUI as a bika cake. Hamka wants to explain to the Muslims that the MUI position is like cooking a bika, if the ignition is too big from the top of it, it will burn on top, and if the ignition is too big from low the part, it will burn the top of it. The dynamism of Hamka's relationship with the government is reflected in several attitudes when he leads the MUI. MUI has issued a fatwa about banning say Christmas day for Muslims, where the fatwa is clearly different from the attitude of the government at that time. Even the difference was made even more apparent when Buya Hamka had to withdraw from her leadership at MUI because of her unwillingness to revoke the fatwa. Becuase of this, Hamka was not very angry with Suharto, but he was disappointed with the Minister of Religious Affairs at that time who seemed to impose his opinion on MUI (Hashim, 2015).

\section{Conclusions}

Hamka and M. Quraish Shihab have similar methods in bring verses taking about power, leadership, and government in the context to Indonesian culture. The method they use is to give a meaning of the verse or its part in general, as an example about who $\bar{u} l \bar{l}$ al-amr is and who or how the leadership (al-Imām) is. Nevertheless, the two mufassirs (the expert of tafsir) also have a striking difference. M. Quraish Shihab tends to feel quite with these common values and if he further elaborated those values, he simply provides a general description of knowledge, such as the principles of leaders in Islam.

Hamka tends to spell out the general principles that have been conveyed with the contextual and actual thoughts of the time, which Hamka believes. For example, on the relationship between religion and state, Hamka tends to be one of the ideas that developed in the period leading up to the breaking of the relationship between religion and state. 
Although, Hamka accepted one of his thoughts, he gave special note, that the management of the state should still be based on the principle of musyawarah.

The context of the interpretation of verses about power, state and government both from tafsir of al-Azhar and al-Mishbāh is relevant to the discourse of power during the periods of the two interpreters. Hamka showed more of his ideology, thus showing a more assertive stance at that time, in which religious and state relations were placed. Quraish Shihab looks more ambiguous and does not support any of the development discourse. So on the one hand, the commentary of al-Mishbāh is open to read by various parties of various religious backgrounds, but on the other side there seems to be no strict alignment, so it can be considered pragmatic. Wallahu A lam.

\section{References}

Abdullah, M. (2001). al-Ta'wīl al-'Ilmi: Ke arah Perubahan Paradigma Penafsiran Kitab Suci. al-Jami ah of Islamic Studies, IAIN Sunan Kalijaga Yogyakarta, 380-381.

Baso, A. (1999). Civil Society versus Masyarakat Madani: Arkeologi Pemikiran "Civil Society" dalam Islam Indonesia. Jakarta: Pustaka Hidayah.

Bleicher, J. (1993). Contemporary Hermeneutics, Hermeneutics as Method, Philosophy, and Critique. London and New York: Routlege.

Dijk, T. A. (2008). Discourse and Context; A sociocognitive approach. New York: Cambridge University Press.

Djajasudarma, F. (2006). Wacana; Pemahaman dan Hubungan Antar Unsur. Bandung: Refika Aditama.

Aljunied, Syed Muhd Khairudin. (2017), "In Defense of Guided Reason: Hamka and the Reconstruction of Southeast Asian Islam" History of Religions, Vol. 57, No. 2.

Federspiel, H. M. (1996). Kajian al-Qur'an di Indonesia dari Mahmud Yunus hingga Quraish Shihab, terj. Tajul Arifin. Bandung: Mizan.

Hamka. (2015). Tafsir al-Azhar. Jakarta: Gema Insani.

Haryatmoko. (2003). Etika Politik dan Kekuasaan . Jakarta: Penerbit Buku Kompas.

Hasyim, S. (2015). Fatwa Aliran Sesat dan Politik Hukum Majelis Ulama Indonesia (MUI)", Al-ahkam ,Volume 25, Nomor 2. al-Ahkam .

Kuntowijoyo. (2004). Islam Sebagai Ilmu, Epistemologi, Metodologi, dan Etika. Bandung: Teraju Mizan.

Muhatarom, A. (2015). The Concept of Satrul 'Aurah According To Hamka's Interpretation In al-Azhar and M. Quraish Shihab Interpretation in al-Misbāh (Comparative Studi). Semarang: Fakultas Ushuluddin UIN Walisongo .

Muhsin, I. (2010). Tafsir al-Qur 'an dan Budaya Lokal (Studi Nilai-nilai Budaya Jawa dalam Tafsir al-Huda Karya Bakri Syahid). Jakarta: Balitbang dan Diklat Kemenag RI.

Mujahidin, A. (2011). Konsep Kekuasaan dalam Tafsir al-Mishbāh Karya M. Quraish Shihab Dan Relevansinya Dengan Transformasi Masyarakat Indonesia . Yogyakarta: Pascasarjana UIN Sunan Kalijaga Yogyakarta.

Mulyana. (2005). Kajian Wacana; Teori, Metode, dan Aplikasi Prinsip-Prinsip Analisis Wacana. Yogyakarta: Tiara Wacana.

Muslim, M. (1989). Mabāhits fì al-Tafsī r al-Maudhū'i. Beirut: Dar al-Qalam.

Najib, A. (2016). Cantextual Qur'an Interpretation: The Studi on The Concept of "Hierarchy of Values" Abdullah Saeed. Journal of Islamic Studies and Culture, 89-94.

Recour, P. (1991). From Text To Action; Essays in Hermeneutics, II. Evanston, Illinois: Northwestern University Press. 
Shihab, M. Q. (2005). Tafsir al-Mishbāh, Pesan, Kesan dan Keserasian al-Qur'an. Jakarta: Lentera Hati.

Shihab, M. Q. (2005). Logika Agama: Kedudukan Wahyu dan Batas-batas Akal dalam Islam. Jakarta: Lentera Hati.

Shihab, M. Q. (1996). Wawasan al-Qur 'an: Tafsir Maudhu’i atas Pelbagai Persoalan Umat. Bandung : Mizan.

Soraya, M. R. (2014). Kontestasi Pemikiran Dasar Negara dalam Perwujudan Hukum di Indonesia. Humanika , 2-3.

Supena, I. (2007). Rekonstruksi Sistematik Epistemologi Ilmu-Ilmu Keislaman dalam Pemikiran Hermeneutika Fazlur Rahman (1919-1988)", Ringkasan Disertasi, Program Pascasarjana UIN Sunan Kalijaga Yogyakarta. Yogyakarta: UIN Sunan Kalijaga.

Wahid, A. (2016). Sosial Politik Dalam Tafsir Hamka. Aceh: Conference ProceedingsARICIs I UIN ar-Raniry.

Zayd, N. H. (2000). Mafhūm al-Nash, Dirāsat fì 'Ulūm al-Qur'ān. Bayrut Libanon: alMarkaz al-Staqafy al-'Araby. 